\title{
O CÓDIGO CIVIL DE 1916: TÃo LIBERAL QUANTO ERA LHE PERMITIDO SER
}

\author{
Adisson Leal ${ }^{1}$ \\ João Paulo Borges ${ }^{2}$
}

\section{RESUMO}

A doutrina tradicional atribui ao Código Civil de 1916 um forte caráter liberal, em decorrência principalmente da influência exercida pelos ideais liberais europeus. Não obstante, o exame do contexto estrutural do Brasil à época revela que o liberalismo atribuído a esse diploma deve ser relativizado. O projeto de lei elaborado por Clóvis Beviláqua foi fortemente influenciado pelo Código Civil alemão, cujo conteúdo liberal é superdimensionado. Pretende-se, aqui, demonstrar que a proposta de Beviláqua foi "tão liberal quanto the era permitido ser", tendo em vista as limitações dadas pela estrutura social agrária e oligárquica e pelo conservadorismo então dominantes no Brasil.

Palavras-chave: Código Civil de 1916. Clóvis Beviláqua. Liberalismo. Contexto estrutural. Oligarquias.

\section{BRAZILIAN CIVIL CODE: AS LIBERAL AS IT COULD BE.}

\begin{abstract}
Traditional legal experts identify on brazilian 1916 Civil Code a strong liberal bias, mainly due to the influence exerted by the european liberal ideas. Nevertheless, the examination of the social and economic structural context at that time reveals that the liberalism attributed to this Law must be relativized. The draft of the Code prepared by Clovis Beviláqua was strongly influenced by the German Civil Code, whose liberal content is overrated. This study intends to demonstrate that Beviláqua's proposal was "as liberal as it could be" bearing in mind the limitations given by the social and agrarian structure and conservative interests.
\end{abstract}

Keywords: 1916 Civil Code. Clóvis Beviláqua. Liberalism. Structural context. Oligarchs.

\section{Introdução}

A data de $1^{\circ}$ de janeiro de 2017 marcou o centenário da entrada em vigor do Código Civil de 1916 (CC/1916), Lei $n^{\circ} 3.071$, de $1^{\circ}$ de janeiro de 2016. Sobre o diploma, algumas características são normalmente reconhecidas como dados indiscutíveis: o caráter eminentemente liberal, os acentuados individualismo, patrimonialismo e patriarcalismo, e a

\footnotetext{
${ }^{1}$ Mestre em Direito Constitucional e doutorando em Direito Civil pela Universidade de Lisboa. Especialista em Direito Civil e Empresarial pela Universidade Potiguar. Graduado em Direito pela Universidade Estadual da Paraíba. Professor do Instituto Brasiliense de Direito Público - IDP.

2 Pós-graduado em Gestão Governamental e Políticas Públicas pela Universidade Cândido Mendes. Graduação em Relações Internacionais pela Universidade de Brasília e em Ciências Econômicas pela União Pioneira de Integração Social. Discente em Direito pelo Instituto Brasiliense de Direito Público. Analista Especialista do Banco Central do Brasil.
} 
marcante influência das ideias predominantes no continente europeu à época. Ademais, foram - e ainda são - constantes as críticas quanto ao forte teor conceitual, ao privilégio exacerbado da autonomia privada, à ausência de direitos trabalhistas e ao distanciamento do viés social.

O projeto do Código de 1916 foi elaborado pelo jurista cearense Clóvis Beviláqua, um dos mais nobres representantes da consagrada Escola do Recife, fortemente influenciada pelos teóricos alemães e pelo Código Civil alemão, o Bürgerliches Gesetzbuch (BGB), de 1896, que logo se tornaria referência mundial e influenciaria fortemente o nosso CC/1916.

Contudo, grande parte dos estudos negligenciam o contexto sociopolítico e cultural em que essa Lei foi elaborada, indispensável à compreensão do seu real espírito. Ademais, a moderna doutrina alemã relativizou o caráter liberal do BGB.

Nesse sentido, o objetivo do artigo é analisar a real extensão do conteúdo liberal atribuído ao CC/1916. Para tanto, será estudados (i) a legislação civil anterior à República, (ii)o contexto sócio-jurídico da República Velha, (iii) o debate entreo autor do projeto de Lei e um importante crítico ao seu trabalho, Rui Barbosa, (iv) as críticas mais comuns atribuídas ao Código, (v) as características não liberais do CC/1916.

\section{A legislação civil anterior à República}

O CC de 1916 pôs fim ao longo período em que vigoraram as Ordenações do Reino, sistema jurídico português aplicável no Brasil que compreendia, primeiro, as Ordenações Afonsinas, depois, as Ordenações Manuelinas e, ao tempo da dominação espanhola, as Ordenações Filipinas. Essas últimas entraram em vigor em 1603 e tratavam-se basicamente de uma consolidação das legislações anteriores.

É importante notar que as Ordenações Filipinas permaneceram aplicáveis em nosso País mesmo após o período da Independência, ainda que elas já tivessem sido revogadas em 1867 pelo Código Civil português, de nítida inspiração napoleônica.

Uma das possíveis razões para tão longa vigência das Ordenações é a abundância de omissões em seu texto, o que lhe conferia um caráter de flexibilidade, permitindo a regência subsidiária dos direitos canônico e romano. Cita-se, ainda, o fato de que, comparativamente a Portugal, o Brasil conservou por mais tempo as condições e formas de vida que conformaram o contexto em que foi editada tal legislação (OLIVEIRA, 2002). 
As ideias liberais, que haviam penetrado em Portugal no começo do século XIX, especialmente o Código Napoleônico, influíram decisivamente na evolução do direito privado português. De modo diverso, o Brasil permaneceu fiel à tradição, principalmente à escravidão (GOMES, 2003).

Havia a impossibilidade, para os tratadistas brasileiros do século XIX, de conciliar um código necessariamente liberal, no qual os direitos de cidadania devessem ser concedidos a todas as pessoas, com o sistema escravista, fundamentado juridicamente na distinção entre pessoas (livres) e coisas (escravos). Era juridicamente inviável tratar da codificação do direito civil sem levar em conta o elemento servil, como o escravo era chamado então (GOMES, 2003).

Apesar disso, o fato de muitas das disposições das Ordenações Filipinas terem sido revogadas, ao longo dos anos, por legislações esparsas tornava imperiosa a tarefa de consolidar as leis civis até então existentes e válidas no país. O escolhido para essa árdua tarefa foi Teixeira de Freitas, em 1855. Segundo esse jurista, as Ordenações Filipinas eram "pobríssimas", e pediam "copioso suplemento", muitas vezes tirados da legislação romana, inadequada à realidade brasileira de então (GRIMBERG, 2001).

Observe-se que o Código Comercial brasileiro fora promulgado em 1850 com relativa facilidade, o que contrastava com os obstáculos que se punham no governo e no Parlamento em relação ao projeto de Código Civil elaborado por Teixeira de Freitas (VERONESE, 2011).

Assim, as ideias liberais:

(...) embora entrecortadas por semânticas normativas de identidade do Estado-nação, elas circulavam, ao seu modo, no discurso político e jurídico do Império brasileiro. Porém, na medida em que pretenderam ganhar força e tomar forma institucional como artefato estrutural de caráter normativo no plano local, elas se expunham a obstáculos quase intransponíveis: o regime escravocrata, pertencente à estrutura econômica da sociedade mundial do século XIX, legitimado por semântica e estrutura normativa local da autenticidade, tornava improvável a institucionalização das ideias liberais individualistas mediante a codificação do direito civil. Daí por que, nessas circunstâncias, em termos estruturais, "só se efetivaria a revogação das Ordenações com o término das relações escravistas" (Mercadante, 1980, p. 194).

À empreitada de Teixeira de Freitas, seguiram-se mais quatro, até a elaboração do projeto do CC/1916: projeto de Visconde de Seabra, em 1871; projeto de Nabuco de Araújo, 
em 1872; projeto de Felício dos Santos, em 1881; e projeto de Antônio Coelho Rodrigues, em 1883. (SALGADO, 2012).

\section{A República e o Liberalismo}

Em Portugal, o ideário iluminista provocou forte reação contra a envelhecida estrutura jurídica medieval, e a Revolução Liberal de 1820 inaugurou um período de influência liberal e individualista no Direito português, sem paralelo no Direito brasileiro (SILVA, 2000). Nesse sentido, o Código Civil português, de fato, rompeu, com a tradição anterior dos moldes da Monarquia.

No Brasil, o fim da escravidão em 1888 e a ascendência das ideias liberais sobre uma pequena elite influenciaram o surgimento de um novo período político no Brasil - a República, marcando o fim do Império.

As ideias do constitucionalismo liberal circulavam no âmbito dos setores civis de uma embrionária 'classe média', ainda muito limitada entre minorias privilegiadas vinculadas principalmente aos latifúndios e massas subalternas ou excluídas no campo e na cidade. Rui Barbosa era uma expressão típica dessa nova classe média.

Convocada a Assembleia Constituinte para redigir a nova Constituição, Rui Barbosa, fascinado pela experiência constitucional dos Estados Unidos, apresentou um anteprojeto de texto Constitucional fortemente embasado nos ideais do liberalismo, do presidencialismo e do federalismo, ideais esses que se consolidaram no texto final aprovado no Congresso, mesmo que ele tenha sofrido alterações (DANTAS, 1962).

Apesar disso, a República manteve os mesmos mecanismos de dominação dos coronéis e o distanciamento do Estado em relação à sociedade. Pouco antes da República, em 1881, as alterações na legislação eleitoral introduzidas pela Lei Saraiva suprimiram o direito de voto de significativa parcela da população e viabilizaram a concentração do poder político nas mãos dos grandes proprietários de terras. Dessa maneira, a proclamação da República soou um tanto inesperada e incompreensível para a população (GOMES, 2003).

Diferentemente de Portugal, não houve no Brasil republicano um rompimento amplo com a ordem anterior. O País manteve-se inspirado na antiga tradição cultural ibérica, alheia ao iluminismo libertário, à ênfase nos direitos naturais e à liberdade individual. As relações civis continuavam inspiradas em aspectos comunitários da vida religiosa e política, bem como 
na supremacia do todo sobre as partes; da cooperação sobre a competição; e da hierarquia sobre a igualdade (GOMES, 20003).

A Constituição Federal de 1891 manteve-se como um mero documento nominal apartado da estrutura social subjacente e da prática política dominante no Brasil à época. Construída à imagem da Constituição norte-americana, por um idealismo utópico ou orgânico, alimentava uma ilusão simbólica de que o simples transplante do modelo constitucional dos Estados Unidos ofereceria uma solução adequada dos problemas sociais brasileiros (NEVES, 2015). O próprio Rui Barbosa reconhecia esse descompasso e assim relatou:

Um dos flagelos que desgraçam hoje este país, são as chamadas oligarquias locais estaduais, que o Governo da União acoroçoa, explora, sustenta e agrava, servindo-se, para isso, já dos exércitos militares de mar e terra, já do exército civil, que o nosso inumerável funcionalismo the proporciona (Barbosa, 1934, p. 17).

Acima de tudo, o período republicano foi marcado por uma dissociação entre política e direito. Do ponto de vista estritamente jurídico-normativo, o texto constitucional tinha pouco significado estrutural para a estabilização generalizada de expectativas normativas no âmbito de uma concretização constitucional satisfatória, de modo que as ações políticojurídicas se desviavam do modelo previsto na Constituição.

Entretanto, na perspectiva política, as ideias liberais incorporadas ao texto constitucional desempenhavam uma relevante função simbólica, tanto porque serviam para certa autoilusão constitucional (NEVES, 2015).

\section{Debate entre Rui Barbosa e Clóvis Beviláqua}

A necessidade de um código civil continuou evidente no imaginário dos juristas, mesmo após as primeiras tentativas. Nesse sentido, sob a influência das ideias liberais e tendo em vista o novo contexto político, em 1890, foi escolhido o jurista Antônio Coelho Rodrigues para elaborar um anteprojeto de Código Civil, mas o projeto não teve andamento na Câmara dos Deputados.

Em seguida, o Presidente Campos Sales propôs a retomada do projeto de edição de Código Civil. A escolha natural para tal empreitada seria Rui Barbosa, que houvera redigido a 
Constituição da República. Contudo, em 1898, Epitácio Pessoa, ministro da Justiça do presidente Campos Sales, escolheu Clóvis Beviláqua para redigir tal Lei.

Essa escolha inicia um amplo debate entre Rui Barbosa e Clóvis Beviláqua que resulta em um atraso de dezessete anos entre o término dos trabalhos desse último, em novembro de 1898, e a promulgação do Código Civil, em 1916.

$\mathrm{O}$ fato de Beviláqua ter se graduado em Direito na mesma turma de Epitácio Pessoa e de ele ser um renomado professor contribuíram para sua escolha em detrimento de Rui Barbosa. Não obstante, a economia política deve ser considerada na análise dessa escolha.

Campos Sales assumiu a Presidência com a tarefa de organizar as finanças do país, visando o pagamento das dívidas anteriores e a obtenção de mais empréstimos. Para isso, Sales tinha de se adequar às imposições dos bancos estrangeiros, em especial dos ingleses (SALGADO, 2012).

Quando Ministro da Fazenda no governo de Deodoro da Fonseca, Rui Barbosa colocou em operação a política do Encilhamento, emissionista de papel-moeda, e buscou não contar com empréstimos externos. O resultado foi o fortalecimento do processo especulativo, que gerou a insatisfação dos credores com os rumos que a economia vinha tomando. Ao defender a recusa ao crédito externo, Rui tornara-se persona non grata frente aos banqueiros (SALGADO, 2012).

Ademais, a política de Encilhamento provocou aumento da inflação e da dívida e depreciação cambial, que geraram dificuldades crescentes de acomodação junto aos Rothschild, então a principal casa financeira internacional. Uma sucessão de empréstimos foi tomada pelo governo brasileiro, mas a situação fiscal somente se agravava (SALGADO, 2012).

Finalmente, o governo brasileiro declarou moratória em 1898/1900 e um plano de refinanciamento (funding loan) foi acertado. Os termos do acordo eram rolar o serviço da dívida pública externa e algumas garantias de juros, em troca de medidas de saneamento fiscal e monetário. Como garantia, o governo Campos Sales forneceria a hipoteca sobre receitas em moeda forte da alfândega do Rio de Janeiro (SALGADO, 2012).

Contudo, a legislação civil brasileira não previa o instituto jurídico da hipoteca. E mais, fazia-se necessário estruturar toda uma lei civil, não mais com base nas Ordenações do Reino, mas com garantias voltadas à economia capitalista. Isso explica o forte interesse de Campos Sales pela edição de um código civil às pressas (SALGADO, 2012). 
A edição de um Código Civil serviria para, ao menos no plano normativo, aproximar o Brasil do capitalismo apregoado pelos ideais liberais. Ainda que Rui Barbosa tivesse redigido o anteprojeto da liberal Constituição de 1891, o momento exigia uma dose de cautela. Por essa razão, o governo não optou por dar a Rui Barbosa a criação do projeto, mas sim a um liberal, crente no evolucionismo, republicano e aberto à influência da economia externa (SALGADO, 2012).

Entretanto, além da questão liberal-econômica, outro importante aspecto marca a edição do Código Civil. Trata-se da dimensão simbólica, marcada pela civilidade e pela linguagem, mais do que preocupações de ordem prática. Não por outro motivo grande parte das críticas de Rui Barbosa ao projeto de Beviláqua foram relativas à linguagem.

Parte da historiografia reduz o debate a uma mera guerra de egos ou a tecnicismos linguísticos, como uma simples oposição filológica, pouco jurídica. Entretanto, as divergências entre esses juristas tinham origem histórica nas rivalidades entre as duas escolas de direito existentes à época: a de Recife, da qual Beviláqua era membro, e a de São Paulo, integrada por Rui Barbosa (GRINBERG, 2001).

Em termos sintéticos, a Escola de Recife foi bastante influenciada pelo naturalismo, pelo evolucionismo e pelo cientificismo e se baseou fortemente nos teóricos alemães. De inspiração iluminista, com fortes crenças no progresso e na razão, essa Escola propunha que as reformas intelectuais deveriam anteceder e fundamentar as demais reformas. Havia um importante interesse filosófico, especialmente à obra Kantiana, nos aspectos relativos à racionalidade, à capacidade de escolher os próprios fins e de ser livre (GOMES, 2015).

De outro modo, a Escola de São Paulo sofreu forte influência do positivismo. Nela, predominava o aspecto jurídico propriamente dito (direito processual e civilista), trazendo consigo características do ordenamento jurídico francês e italiano. As doutrinas francesa e italiana da época, que inspiraram fortemente a Escola de São Paulo, defendiam a tese de que o Código deveria esgotar toda matéria de direito privado. Havia, nesse sentido, um forte viés legalista e uma preocupação com o rigor linguístico (GOMES, 2015).

De certo modo, o que Rui Barbosa estava a defender era que os conceitos jurídicos requeriam uma expressão literária que fosse elegante, com vistas à clareza e à compreensão, com minoração das ambiguidades. Dessa maneira, incluiu no debate a discussão sobre estilo da produção legislativa. Suas intervenções tinham por pano de fundo a necessidade de uma 
legislação moderna, ordenada e lógica (VERONESE, 2011). Merece destaque outro trecho da Réplica:

\begin{abstract}
Se a lei não for certa, não pode ser justa: 'Legis tantum interest ut certa sit, ut absque hoc nec justa esse possit'. Para ser, porém, certa, cumpre que seja precisa, nítida, clara. E como ser clara, se for vazada nos resíduos impuros de um idioma de aluvião? Se não se espelhar nessa língua decantada e transparente, que a tradição filtrou no curso dos tempos? Aspirar à clareza, à simplicidade e à precisão sem um bom vocabulário e uma gramática exata seria querer o fim sem os meios. A lucidez no estilo das leis 'depende, a um tempo, da lógica e da gramática', diz Bentham, 'ciências que é mister possuir a fundo, para dar às leis redação boa' (Brasil, 1902, p. 304).
\end{abstract}

Um dos motivos da forte crítica de Rui Barbosa à Beviláqua estava centrado na velocidade que o governo buscou imprimir ao processo legislativo, o que poderia impor maiores dificuldades na vida prática do direito brasileiro. À medida que os dados foram sendo desnudados, nota-se que a ação política de Rui Barbosa surtiu efeitos desejados, já que obrigou a realização de um debate mais aprofundado sobre o projeto original, em vez de permitir um fluxo célere e pouco refletido.

De modo diverso, a doutrina que mais influenciou a Escola de Recife, e consequentemente Beviláqua, foi o usus modernus pandectarum do direito germânico, que se baseava na concepção de que o jurista está acima do legislador. Dessa maneira, o autor do projeto do CC/1916 não defendia a tese de autossuficiência do Código. Ao contrário, para ele, seria natural a posterior especialização do direito civil em outras leis e isso não tiraria papel central do jurista de completar o sentido da norma, mas o auxiliaria nessa tarefa.

Apesar dessas divergências, a doutrina tradicional desconsidera as diferenças filosófica-jurídicas entre Beviláqua e Rui Barbosa e interpreta o debate como discussões de questões meramente linguísticas, principalmente pelo fato de ambos terem sido fortemente influenciados pelas ideais do Liberalismo.

Nesse sentido, é comum encontrarmos textos do campo jurídico que asseveram que o CC/1916 seria um documento de substrato eminentemente liberal e que esse paradigma teria sido suplantado com o surgimento do Estado Social, as legislações esparsas, além de ter sido absolutamente superado a partir da Constituição Federal de 1988 e do Código Civil de 2002.

Não obstante, a influência da doutrina alemã e os aspectos filosóficos e evolucionistas da Escola de Recife, bem como a realidade sócio-política do Brasil à época, 
levam-nos a examinar mais detidamente a tese do liberalismo exacerbado atribuído ao $\mathrm{CC} / 1916$.

\section{A concepção tradicional sobre o Código Civil de 1916}

Na doutrina, tornou-se dominante a visão de que o CC/1916 era eminentemente individualista e possuía um forte conteúdo do liberalismo, quase egoístico, que impregnou a codificação napoleônica e, de resto, os vários diplomas à época promulgados (GRINBERG, 2001). Em essência, é tido como um código oitocentista, embora nascido no século XX. (LÔBO, 2002).

As relações jurídicas de direito privado à luz desse Código estariam regidas pelo patrimonialismo, bem distinta da visão do Estado Social, que viria a surgir depois na Europa (SOARES; BARROSO, 2006). Em termos gerais, essa Lei outorgava primazia à autonomia da vontade no tocante aos ajustes particulares só admitindo o rompimento do vínculo na hipótese da verificação de atos ilícitos (REALE, 2001), ou no caso de anuência das partes que o avençaram (RODRIGES, 1967).

Nesse sentido, não havia qualquer limitação ao poder de contratar, a exemplo da onerosidade excessiva, prevista no Código de 2002. A liberdade individual não era ponderada por interesses sociais ou de bem-estar do grupo, travestindo-se em indesejado individualismo, para a doutrina tradicional (SANTOS, 2003).

Segundo Fachin (2003):

os três pilares fundamentais, cujos vértices se assenta a estrutura do sistema privado clássico, encontram-se na alça dessa mira: o contrato, como expressão mais acabada da suposta autonomia da vontade; a família, como organização social essencial à base do sistema, e os modos de apropriação, nomeadamente a posse e a propriedade, como títulos explicativos da relação entre as pessoas sobre as coisas (Fachin, 2003, PP. 12-13).

Dessa maneira, a eticidade do Código estaria baseada na igualdade formal, desconsiderando as reais condições sociais dos indivíduos concretos, que eram indiferentes para a ordem jurídica liberal.

Assentado em um sistema interno fechado, lógico-dedutivo, era tímida a utilização, no CC/1916, de cláusulas gerais, de princípios e de conceitos jurídicos indeterminados, uma vez que os seus dispositivos eram elaborados predominantemente segundo a técnica 
legislativa casuística. Tal característica teria dificultado sobremaneira a ocorrência de mutações e a atividade judicial criativa, do que decorreu uma rigorosa incomunicabilidade com a realidade e, por conseguinte, a inadequação do código para a normatização de uma sociedade mais complexa e diferenciada.

A família era eminentemente patriarcal e o divórcio não era admitido não tanto por influência da Igreja Católica, mas sobretudo por força das ideias de Augusto Comte. A propriedade era compreendida segundo a tradição liberal, e as poucas restrições provinham do direito de vizinhança. Já o direito contratual tinha sua fonte na autonomia da vontade, não se verificando as concretas forças da desproporção do poder de discutir as cláusulas contratuais entre as partes. Não houve, portanto, a adoção da doutrina da cláusula rebus sic standibus (COUTO E SILVA,1964).

Em outras palavras, o CC/1916 é tido como uma legislação formalista que teria adotado uma concepção ética do sujeito de direito abstrato e desprovido de qualquer atributo social diferenciador. Para a concepção tradicional, o individualismo consistiu um elemento consciente no trabalho de Clovis Beviláqua, que teria considerado inadequada a inserção, no texto legal, de preceitos consagradores das demandas sociais em virtude de não estarem, à época, devidamente assentadas e reconhecidas (VELLOSO, 2004).

\section{Código Civil de 1916: liberal, até que ponto?}

Em sua análise sobre a influência do Código Civil Alemão (Bürgerliches Gesetzbuch - BGB), Rodrigues Júnior (2013) propõe a relativização de um consenso bastante arraigado no Brasil: a natureza liberal, exegética e patrimonialista do Código Civil alemão. Segundo o autor, em certa medida, esse é um consenso transponível ao CC/1916, tantas vezes apontado como uma lei retrógrada e velha em seu próprio tempo. Além disso, cumpre questionar se o Brasil do século XIX, atrasado, rural e centralista, pode ser realmente considerado um exemplo de liberalismo? Em última instância, esta seção busca examinar até que ponto o CC/1916 era uma lei eminentemente liberal.

5.1 A contraposição à tradicional visão do BGB como código liberal 
Há um certo consenso entre grandes juristas alemães acerca do caráter liberal do BGB, caracterizando-o como uma obra de defesa da propriedade absoluta e da família tradicional,. Não por acaso essa mesma visão recai sobre o nosso Código de 1916, de forma que as críticas ao BGB se aplicam indiretamente à lei civil brasileira do início do século.

A influência alemã na formação do Direito Civil brasileiro ocorreu de forma indireta e direta. Indiretamente, o direito alemão influenciou o direito português e, consequentemente, as Ordenações que vigoravam no Brasil. Diretamente, a influência mais importante foi a do BGB sobre o processo de elaboração do CC/1916.

Inicialmente, deve-se esclarecer que o universo acadêmico alemão era inacreditavelmente complexo para se atribuir ao BGB um puro e simples qualificativo de código "burguês" ou "liberal". Além disso, eram relevantes as contradições de uma Alemanha, ao mesmo tempo, rural e industrial; aristocrática, burguesa e operária; católica e protestante. Muitas reservas legislativas ao BGB foram aprovadas mantendo-se em vigor alguns estatutos locais, que preservavam antigos costumes dos reinos, grãs-ducados e principados alemães (RODRIGUES JUNIOR, 2013).

Muitas das críticas ao BGB refletem concepções de conteúdo nacional-socialista. Com o pós-guerra, muitos dos membros da Magistratura Alemã foram convidados a participar do processo de reconstrução do Direito, reforçando a visão crítica ao Código, tendo em vista a concepção totalitária do regime nazista. A ridicularização do 'direito subjetivo' como categoria, após 1933, deu-se em um contexto de total aversão a esse importante legado do BGB (RODRIGUES JUNIOR, 2013).

Outra crítica comum ao BGB é de que seria um código de clara inspiração do positivismo científico. Contudo, o Código não tencionava vincular o juiz como se ele fosse a 'boca da lei', mas sim a um grupo de casos presente em suas seções. Se não era casuísta, o BGB também não era jusnaturalista. Uma dose de formalismo era uma forma de proteção contra o totalitarismo.

Além disso, critica-se o BGB sob o argumento de ausência do caráter social, tendo se esquecido do proletariado. Os valores sociais teriam sido ignorados pelo BGB, que teria se concentrado em um egoísmo estéril, baseado na concepção de indivíduo, no dogma da vontade e na propriedade absoluta.

Entretanto, no processo de codificação desse Código, não houve desprestígio ao contrato de trabalho ou a qualquer matéria afim. O BGB não tratou qualquer classe social de 
modo diferenciado. Na realidade, sob os ideais da igualdade e da liberdade, opôs-se aos ideais da aristocracia. Em realidade, o Código alemão não teve por ideal social o cidadão-possuidor isolado, mas uma sociedade formada por pessoas iguais e livres. Não se pode atribuir-lhe a falta de igualdade material do proletariado (RODRIGUES JUNIOR, 2013).

\subsection{A contradição entre o liberalismo e a estrutura social brasileira à época}

O CC/1916 foi elaborado a partir de uma realidade típica de uma sociedade colonial. Em 1882, a população brasileira era essencialmente agrícola, formada basicamente de pobres por inércia. No total, era composta de 9.930.478 habitantes, sendo um milhão e meio de escravos, um milhão de índios, cinco milhões de agregados em fazendas e engenhos e trezentas ou quatrocentas mil pessoas pertencentes às famílias de proprietários de escravos, os fazendeiros e os senhores de engenho. Além disso, devemos mencionar que não havia no país uma classe proletária relevante no sentido socialista porque havia poucos operários ou empregados fabris, de modo que a questão social que eclodiria na Europa não ocorria no Brasil (GOMES, 2003).

Apesar disso, o Código ganhou uma feição liberal que não condizia com os ideais políticos dominantes (GOMES, 2003). A burguesia mercantil, ainda incipiente, objetivava o pleno liberalismo econômico, diversamente da classe agrária, que não concordava com tal ideia e que dominava a política à época.Entretanto, havia uma relação simbiótica entre essas duas classes. Enquanto os proprietários de terra podiam resguardar-se de investidas contra seus interesses fundamentais, o regime de franquias liberais aproveitava, tão somente, a um reduzido número, sendo estranho à grande maioria da população miserável e inculta (GOMES, 2003, P, 46).

Em outras palavras, a classe agrária tinha plena convicção de que o CC/1926 não alcançaria a maior parcela da população. A esse respeito, Pontes de Miranda (1928) que o projeto de Beviláqua era uma codificação para as Faculdades de Direito, mais do que para a vida. Esse nobre jurista cita como exemplo o instituto do contrato de prestação de serviço, incompatível com as relações de criadagem.

O CC/1916 refletia, portanto, o ideal europeu de justiça dessa classe média, mal adequada às condições de vida do interior do país, traduzindo mais as aspirações civilizadoras 
dessa elite, embora progressista, do que os sentimentos e as necessidades da grande massa da população, em condições de atraso.

O caráter liberal refletia o ideal europeu e era limitado, assim, pela própria estrutura social do Brasil e não coaduna com a própria natureza das normas jurídicas, cujo conteúdo é dado pela interpretação com base na realidade fática. $\mathrm{O}$ próprio regime do Coronelismo impedia o efetivo exercício dos direitos apregoados pelo liberalismo. "De mais a mais, o Código era um produto de seu tempo, e, de um lado granjeia econômicos por seu apuro técnico e rigor vernacular, por outro é criticado por sua timidez e excessivo apego ao passado" (CARVALHO, p. 57).

Em outras palavras, a natureza de um processo de codificação é, antes de tudo, dialética. No Brasil, perpetuava-se a velha tradição ibérica alheia ao Iluminismo e baseada nos ideais comunitários da vida religiosa e política, baseada na supremacia do todo sobre as partes, da cooperação sobre a competição e o conflito, da hierarquia sobre a igualdade (SILVA, 2000).

5.3 O Código Civil de 1916 em comparação com o projeto de Beviláqua

\title{
5.3.1 O direito de família
}

A normatização do direito de família no CC/1916 exibe o retrato de um país conservador em relação ao direito de família. Segundo Neves (2015):

\begin{abstract}
A semântica jurídica liberal da sociedade mundial era não apenas entrecortada por ideias antiliberais ou não liberais dos juristas, mas também por estruturas sociais incompatíveis com o individualismo liberal. Isso repercutiu no próprio texto do código, especialmente no tratamento do direito de família. Portanto, no plano das estruturas jurídicas, a institucionalização mediante produção textual já implicava certo deslocamento das ideias liberais de codificação (Neves, 2015, p. 17).
\end{abstract}

Em termos gerais, esse Código manteve-se fiel à tradição e ao estado social, conservando a indissolubilidade do matrimônio e o regime de comunhão universal. Além disso, o casamento do menor de 21 anos necessitava do consentimento de ambos os pais, mas, havendo discordância, prevalecia a vontade paterna, sendo clara a supremacia do homem como cabeça do casal (GOMES, 2003). A família do Código Civil de 1916 era uma família transpessoal, hierarquizada e patriarcal. 
Não obstante, deve-se atentar que o projeto de Bevilaqua, em pontos fundamentais de direito de família, mostrou-se menos insensível às transformações sociais do que o Código Civil aprovado em 1916. A principal barreira conservadora encontrava-se no próprio Congresso Nacional.

O projeto de Beviláqua foi bem mais favorável à situação jurídica dos então chamados 'filhos ilegítimos' do que a solução adotada no Código Civil, uma vez que admitia o reconhecimento dos filhos ilegítimos e a investigação de paternidade (SILVA, 2008).

Além disso, sua posição foi contrária à incapacidade relativa da mulher casada para todos os atos da vida civil. $\mathrm{O}$ art. 279 do projeto de Beviláqua dispunha que "torna-se a mulher companheira e sócia do marido", diferentemente do Código Civil, que dispunha assumir a mulher, pelo casamento, "a condição de sua companheira, consorte e auxiliar no encargo doméstico" (BEVILAQUA, 1906).

Cabe citar, ainda, um importante episódio durante a tramitação do projeto na Câmara dos Deputados. Enquanto o projeto de Beviláqua previa que as mulheres casadas seriam incapazes relativamente a certos atos enquanto subsistisse a sociedade conjugal, a emenda do Deputado Andrade Figueira dispunha que as mulheres casadas seriam incapazes relativamente a certos atos enquanto subsistisse o poder marital. Na prática, essa emenda tornava a mulher perpetuamente incapaz perante o marido, mesmo se houvesse o desquite (MARQUES, 2004).

Andrade Figueira era contra qualquer hipótese de divórcio, inclusive o culposo, argumentando que a dissolução da sociedade conjugal era moralmente negativa e possibilitava abusos e fraudes a credores em caso de falência, porque implicava na separação dos bens do casal, podendo cada um, a partir da sentença de divórcio, administrar livremente os bens que lhe competissem.

Ao comentar essa emenda, Beviláqua assim dispôs:

O desquite põe termo à vida em comum, separa os cônjuges, restitui-lhes a liberdade, permite-lhes dirigir-se, como entenderem, na vida, sem que dependa um do outro, no que quer que seja; mas conserva íntegro o vínculo do matrimônio. Podendo governar, livremente, a sua pessoa, e, livremente, gerir os seus bens, não se pode qualquer dos cônjuges casar, enquanto viver o outro, porque o casamento é um laço perpétuo e indissolúvel, que só com a morte se rompe (Beviláqua, 1917, p. 268).

Separados os cônjuges, tornam-se eles, um em relação ao outro, pessoas estranhas, desaparecendo as obrigações recíprocas, criadas pelo casamento, e subsistindo, apenas, as que 
nascerem do desquite. (...) Ainda que não tenha atingido aos vinte e um anos, não volve à condição de incapaz, sob o pátrio poder ou sob a tutela, poderes dos quais o casamento a libertou (BEVILÁQUA, 1917, pp. 282-283).

Embora não fosse um defensor do divórcio incondicional, Beviláqua o admitia no caso de condutas culposas, e seu projeto previa maior igualdade de gênero do que o texto final do CC/1916. De acordo com o jurista:

Desenvolvendo o mesmo pensamento, procurando atender às justas aspirações femininas e querendo fazer do casamento uma sociedade igualitária, embora sob a direção do marido, concedeu o Projeto maior soma de direitos, maior liberdade de ação à mulher casada do que o direito que atualmente vigora entre nós (Beviláqua, 1917, pp 93-94).

O Projeto tencionou reconhecer na mulher um ser igual ao homem, mas sem desviála das funções que lhe indica a própria natureza, racionalmente interpretada (BEVILÁQUA, 1917, p 95).

Nesse sentido, reconhecendo o conservadorismo que permeava a sociedade brasileira da época, Beviláqua ponderou: "o autor do Projeto tem convicção de que foi, neste ponto, tão liberal quanto lhe era permitido ser" (BEVILÁQUA, 1917, p. 96).

Assim, no processo de codificação do CC/1916, as ideias liberais do direito privado individualista eram entrecortadas pelo conservadorismo e das condições locais e isso repercutiu no direito civil brasileiro, especialmente no direito de família (NEVES, 2015).

\subsubsection{A questão trabalhista}

É comum encontrarmos obras que reforçam o caráter liberal do CC /1916 pelo fato de nele não constar regras de direito do trabalho. Tais visões, contudo, desconsideram o ambiente em que se produziu o Código: à época, não havia no Brasil uma massa de operariado significativa e nem uma questão social eminente. As relações de trabalho ainda estavam impregnadas de concepções escravistas, principal razão para a demora para se elaborar um código civil brasileiro.

A ausência da institucionalização dos contratos de trabalho se deve mais à influência do conservadorismo do que a uma aversão ao social. Tanto é assim que o projeto original de Beviláqua era bem mais adiantado do que o resultante da revisão no Congresso Nacional. 
Entre as normas por ele propostas, e excluídas do Código, figuravam o direito à percepção do salário no caso de impedimento transitório de trabalhar por motivo de doença (art. 1369); o dever de assistência médica ao trabalho doméstico (art. 137); a proibição do trabalho industrial ou das minas aos menores de 12 anos (art. 1381); a limitação a seis horas do tempo de trabalho de menores de 16 anos (art. 1382); o dever do empregador de eliminar as condições de insalubridade sob pena de responder por suas consequências (art. 1383) (NEVES, 2015).

A questão trabalhista não representava, na prática, uma demanda da sociedade. É claro que havia uma certa organização e mobilização proletária, a exemplo do Centro das Classes Operárias, uma entidade anarcosindicalista extremamente ativa naqueles dias. Entretanto, a questão social e a influência socialista não conformavam, de forma significativa, a realidade brasileira.Dessa forma, a ausência desses direitos trabalhistas justifica-se mais pelo atraso socioeconômico do país do que de fato por um triunfo dos ideais liberais.

\section{Conclusão}

O período de 1857 a 1919 foi marcado por diversas tentativas de edição de um código civil brasileiro, pondo fim ao longo período de vigência das Ordenações Filipinas. No cerne da dificuldade de elaboração dessa Lei estava a questão escravocrata, além da incompatibilidade entre o individualismo jurídico e as condições objetivas da realidade brasileira.

O fim da escravidão, a proclamação da República e a edição de uma Constituição liberal abriram caminho para a edição do Código Civil. Ganhavam força os ideais do liberalismo, de forte inspiração europeia, encampados principalmente pela classe burguesa incipiente.

Esses ideais, aliados à dependência econômica do governo a empréstimos estrangeiros e ao fracasso da política de Encilhamento, influenciaram a escolha de Beviláqua, em detrimento de Rui Barbosa, para a elaboração do Código Civil, a pedido de Campos Sales.

Entretanto, tais fatos não implicaram a hegemonia de um pensamento liberal no Brasil. Pelo contrário. À época, o país era formado por uma grande massa agrária, miserável e inculta, uma incipiente classe média liberal, além dos grandes latifundiários, verdadeiros 
detentores do poder. A população brasileira assistiu bestializada à proclamação da República em 1889.

Em outras palavras, o período republicano não pôs fim ao domínio político das oligarquias locais. Na realidade, originou uma relação simbiótica entre os grandes latifundiários e a classe burguesa.

A edição de um código privado de feição liberal resguardava os proprietários de terra contra seus interesses fundamentais e satisfazia os interesses da burguesia incipiente, aproveitando, tão somente, a um reduzido número, sendo estranho à grande maioria da população. Acima de tudo, o período republicano foi marcado por uma dissociação entre política e direito.

O contexto de edição do CC/1916 foi caracterizado, portanto, pela convivência de ideais liberais incipientes e pela permanência dos ideais conservadores. Fortemente influenciado pelo naturalismo, pelo evolucionismo e pelo cientificismo e pelos teóricos alemães, Beviláqua empreendeu esforços de redigir um Código tão liberal quanto lhe era permitido ser, dadas as limitações impostas pela própria estrutura social agrária e oligárquica do Brasil.

Membro da Escola de Direito de Recife, e influenciado pelo usus modernus pandectarum do direito germânico, Beviláqua não propôs um Código autossuficiente e hermético, como afirma a doutrina civilista tradicional.

Seu projeto foi fortemente influenciado pelo BGB, que, ao contrário da visão comum, não pode ser rotulado como "burguês" ou "liberal". O Código alemão manteve em vigor alguns estatutos locais, que preservavam antigos costumes dos reinos, grãs-ducados e principados alemães. Além disso, não tinha uma visão positivista de juiz como 'boca da lei', apesar de não ser casuístico, como propunha a visão totalitária defendida pelo regime nazista. Opondo-se aos ideais da aristocracia, o BGB teve, assim, por ideal social não o cidadãopossuidor isolado, mas uma sociedade formada por pessoas iguais e livres.

Diversamente, Rui Barbosa, crítico feroz ao projeto do jurista da Escola de Recife, possuía mais forte viés positivista e uma preocupação com o rigor linguístico. Barbosa era membro da Escola de São Paulo, fortemente influenciada pelo direito francês, de clara inspiração da autossuficiência e do positivismo do Código napoleônico.

Tal como o BGB, a igualdade formal prevista no Código Beviláqua permitiu que não se tratasse qualquer classe social de modo diferenciado. Sob os ideais da igualdade e da 
liberdade, contrapunha-se, ainda de que forma tímida, à cristalização das desigualdades do regime oligárquico.

Nesses termos, deve-se entender a natureza do CC/1916 com base no contexto histórico em que ele foi produzido. Em uma realidade de virtual ausência da classe proletária e de dominação oligárquica, o projeto Beviláqua mostrou-se menos conservador e mais preocupado com as questões sociais do que a versão final aprovada pelo Congresso, principalmente em matéria de direito de família.

Dessa maneira, o que se procurou demonstrar nesse artigo é que, ainda que não se possa negar a influência do pensamento liberal sobre a formulação do CC/1916, o rótulo a ele atribuída de eminentemente liberal desconsidera a realidade brasileira à época, marcada pela dominação oligárquica e pelo conservadorismo, que permeiam não só o texto da Lei, mas também a sua interpretação. As normas do CC de 1916 não podem ser dissociadas do contexto estrutural do país, entrecortado por interesses da elite agrária, e no qual a grande massa da população permanecia alheia aos institutos liberais.

\section{Referências bibliográficas}

BARBOSA, 1934, in: NEVES, Marcelo: Ideias em outro lugar? Constituição liberal e codificação do direito privado na virada do século XIX para o século XX no Brasil. Revista Brasileira de Ciências Sociais nº 88, junho, 2015.

BARROSO, Lucas Abreu; SOARES, Mário Lúcio Quintão. A dimensão dialética do novo código civil em uma perspectiva principiológica. In: Lucas Abreu Barroso (Org.). Introdução crítica ao código civil. Rio de Janeiro: Forense, 2006. p. 1-14.

BEVILAQUA, Clóvis. Em defesa do Projeto de Código Civil Brasileiro, 1906 (Trecho).

BEVILAQUA, Clóvis. Código Civil dos Estados Unidos do Brasil comentado por Clóvis Bevilácqua. Rio de Janeiro: Livraria Francisco Alves, 1917, v. LT, p. 268.

BRASIL. Senado Federal. Rio de Janeiro. Obras Completas de Rui Barbosa. V. 29, t. 3, 1902. p. 399-400.

CARVALHO, José Murilo. Cidadania no Brasil. Rio de Janeiro: Civilização Brasileira, 2005. Pg 57.

COUTO E SILVA, Clóvis V. O direito civil brasileiro em perspectiva histórica e visão de futuro. Brasília, Senado Federal, Serviço de Informação Legislativa, 1964. 
DANTAS, 1962, in: NEVES, Marcelo: Ideias em outro lugar? Constituição liberal e codificação do direito privado na virada do século XIX para o século XX no Brasil. Revista Brasileira de Ciências Sociais nº 88, junho, 2015.

FACHIN, Luiz Edson. Teoria crítica do direito civil. Rio de Janeiro: Renovar, 2003. p. 12-13

GOMES, Orlando. Raízes históricas e sociológicas do Código Civil brasileiro. São Paulo:

Martins Fontes, 2003.

GRINBERG, Keila. Código civil e cidadania. Rio de Janeiro: Jorge Zahar, 2001.

LÔBO, Paulo. Princípios sociais dos contratos do CDC. Revista Jurídica da Unirondon - $\mathrm{n}^{\mathrm{o}}$ $3 / 2002-12$

MARQUES. Teresa Cristina de Novaes. A mulher casada no Código Civil de 1916. Ou, mais do mesmo. Textos de História, vol. 12, nº 1/2, 2004.

MERCADANTE, Paulo. (1980), "A dualidade do direito privado", in A consciência conservadora no Brasil: contribuição ao estudo da formação brasileira. 3. ed. Rio de Janeiro, Nova Fronteira, pp. 177-194.

NEVES, Marcelo: Ideias em outro lugar? Constituição liberal e codificação do direito privado na virada do século XIX para o século XX no Brasil. Revista Brasileira de Ciências Sociais $n^{\circ} 88$, junho, 2015.

OLIVEIRA, Adriane Stoll de. A codificação do Direito. Jus Navigandi, Teresina, ano 7, n. 60, 1 nov. 2002. Disponível em: <http://jus.uol.com.br/revista/texto/3549>. Acesso em: 28 ago. 2016.

PONTES DE MIRANDA,Francisco Cavalcanti. ([1928] 1981), Fontes e evolução do direito civil brasileiro. 2. ed. Rio de Janeiro, Forense.

REALE, Miguel. Visão geral do projeto do Código Civil. Revista da Associação dos Magistrados Brasileiros, Rio de Janeiro, n.5, p. 66, 2001.

RODRIGUES JÚNIOR, Otávio Luiz. A influência do BGB e da doutrina alemã no direito civil brasileiro do Século XX. Revista dos Tribunais, São Paulo: RT, v. 938, p. 79-155, dez. 2013.

RODRIGUES, Silvio. Direito Civil. 3. edrev.e aum. São Paulo: Max Limonad, 1967.v.3.)

SALGADO, Gisele Mascarelli. Discussões legislativas do Código Civil de 1916: Uma revisão historiográfica. In:Âmbito Jurídico, Rio Grande, XV, n. 96, jan 2012.

SANTOS, José Camacho. O novo Código Civil brasileiro em suas coordenadas axiológicas: do liberalismo a socialidade. Revista Jurídica Virtual - Brasília, vol. 4, n. 45, fev. 2003 
SILVA, Nuno J. Espinosa Gomes da. História do Direito português: fontes de Direito. 3. ed. Lisboa: Fundação CalousteGulbenkian, 2000 in Sampaio Júnior, Da Dinastia de Aviz a Miguel Reale: Ensaio sobre a formação do Direito Civil Brasileiro e seus reflexos na contemporaneidade.

SILVA, Wilton, C.L. As palavras encantadas: retórica, dialeto de conduta e pensamento institucional no discurso jurídico. $32^{\circ}$. Encontro Anual da ANPOCS - Caxambu - 2008.

VELLOSO, Andrei Pitten. Mutações paradigmáticas da Codificação do Código Civil de 1916 ao Código Civil de 2002. Revista da Procuradoria-Geral do Estado [do Rio Grande do Sul]. Porto Alegre. Procuradoria-Geral do Estado do Rio Grande do Sul, 2004.

VERONESE, Alexandre. Entre os dispositivos conceituais e a gramática: o direito e a política na formação do Código Civil de 1916. V Congresso do Instituto Brasileiro de História do Direito. Curitiba, 2011. 